\title{
Impak Pembangunan Pelancongan Terhadap Komuniti Pulau: Kajian Di Pulau Tioman, Malaysia
}

\author{
Md Shafiin Shukor*, Norlida Hanim Mohd Salleh, Siti Hajar Idris
}

Pusat Pengajian Ekonomi, Fakulti Ekonomi dan Pengurusan, Universiti Kebangsaan Malaysia, 43600 UKMBangi, Selangor, Malaysia

*Corresponding author: p80550@siswa.ukm.edu.my

\begin{abstract}
Tourism development is an agent of change to the economic, social and culture of local communities and should make a difference to the environment. These changes may impact either in a positive or negative way. The objective of this study is to analyze the level of agreement of local communities on the development of tourism in the view of economic, social, cultural and environmental impact towards the lives of local communities in tourist destinations, Pulau Tioman. This research is using Smart Partial Least Square 3 (SmartPLS 3) to analyse 228 respondents. The study found that tourism development brings a positive impact on local communities from all aspects. It also found that tourism development can improve the welfare and satisfaction level in life of local communities. Therefore, the development of tourism in tourist destinations like Pulau Tioman can be used as a model for the development of tourism in the other new destinations.
\end{abstract}

Keywords: Tourism development, tourism destinations, tourism.

Abstrak

Pembangunan pelancongan merupakan ejen perubahan kepada ekonomi, sosial dan budaya komuniti tempatan serta membawa perubahan ke atas alam sekitar. Perubahan ini mungkin membawa impak sama ada dalam bentuk positif mahupun negatif. Objektif kajian ini adalah untuk menganalisis tahap kebersetujuan komuniti tempatan terhadap pembangunan pelancongan dari aspek ekonomi, sosial, budaya dan alam sekitar serta impak pembangunan pelancongan ke atas kehidupan komuniti tempatan di destinasi pelancongan Pulau Tioman dengan menggunakan perisian Smart Partial Least Square 3 (SmartPLS 3) terhadap 228 orang responden. Hasil kajian mendapati bahawa pembangunan pelancongan membawa kesan positif kepada komuniti tempatan dari kesemua aspek. Kajian ini turut mendapati bahawa pembangunan pelancongan meningkatkan kesejahteraan dan kepuasan dalam kehidupan komuniti tempatan. Oleh itu, pembangunan pelancongan di destinasi pelancongan Pulau Tioman boleh dijadikan model kepada pembangunan pelancongan di destinasi baru.

Kata kunci: Pembangunan pelancongan, destinasi pelancongan, pelancongan.

(C) 2017 Penerbit UTM Press. All rights reserved

\subsection{PENGENALAN}

Pembangunan pelancongan dilihat mampu menjadi ejen perubahan kepada ekonomi komuniti tempatan. Ini kerana, pembangunan pelancongan menyumbang kepada ekonomi masyarakat seperti pembentukan peluang pekerjaan dan pembangunan industri kecil dan sederhan (IKS). Malah, pembangunan pelancongan juga menjadi ejen perubahan kepada sosial budaya komuniti tempatan yang mana perubahan ini dipengaruhi oleh keadaan persekitaran semasa. Justeru itu, pembangunan pelancongan adalah penting untuk melibatkan komuniti tempatan dan perlu diambilkira. Selain itu, pembangunan pelancongan juga membawa perubahan kepada alam sekitar kerana aktiviti pelancongan biasanya melibatkan penggunaan sumber alam sekitar.

Perubahan faktor ekonomi, sosial, budaya dan alam sekitar berupaya membawa impak sama ada dalam bentuk positif mahupun negatif ke atas komuniti tempatan. Perubahan faktor ini dinilai oleh komuniti tempatan berdasarkan impak yang mereka peroleh secara langsung atau tidak langsung. Lazimnya komuniti tempatan menunjukkan reaksi ketidakbersetujan terhadap kesan negatif dan reaksi bersetuju terhadap kesan positif yang dapat meningkatkan kepuasan dan kesejahteraan dalam kehidupan. Selain itu, pembangunan pelancongan dikatakan berjaya adalah dengan mengetahui impak kepada komuniti tempatan. Di mana, pembangunan pelancongan yang mampu membawa kepada kesejahteraan dan kepuasan kepada komuniti tempatan akan mendapat sokongan dari mereka. Oleh itu, menyedari pembangunan pelancongan mendapat reaksi daripada komuniti tempatan, satu tinjauan terhadap pembangunan pelancongan di salah satu destinasi pelancongan utama Malaysia iaitu Pulau Tioman menarik perhatian untuk dikaji.

Objektif kajian ini bertujuan untuk menganalisis tahap kebersetujuan dimensi atau item faktor ekonomi, sosial, budaya dan alam sekitar serta menganalisis tahap kesejahteraan dan kepuasan komuniti tempatan terhadap pembangunan pelancongan di Pulau Tioman. 
Kerangka kepada perbincangan bagi kajian ini adalah diikuti oleh perbincangan teoritikal model dan kajian lepas, metodologi, hasil kajian dan kesimpulan.

\subsection{TEORITIKAL MODEL DAN KAJIAN LEPAS}

Secara umumnya, pembangunan merupakan satu proses yang mana membolehkan manusia menikmati manfaat daripadanya. Pembangunan bukan sahaja mengambilkira aspek fizikal iaitu infrastruktur, malah ia melibatkan proses menyusun dan menyelaras sistem ekonomi serta mengambilkira perubahan institusi sosial, adat resam dan kepercayaan komuniti setempat. Dalam konteks pelancongan, pembangunan mengambilkira sumbangannya terhadap komuniti tempatan yang meliputi pelbagai faktor seperti ekonomi, sosial dan budaya. Selain itu, pembangunan pelancongan juga melibatkan proses membangun, menyusun dan menaik taraf infrastruktur sesebuah kawasan pelancongan dengan mengambilkira faktor alam sekitar.

Berdasarkan teori pembangunan kelestarian (Emas, 2015), pembangunan merangkumi tiga (3) faktor utama iaitu pembangunan ekonomi, pembangunan sosial budaya, pembangunan alam sekitar. Pembangunan ekonomi bermaksud pembangunan yang dapat mencipta peluang pekerjaan kepada komuniti tempatan atau komuniti tempatan mencipta perniagaan berasaskan pelancongan. Pembangunan sosial budaya pula ialah pembangunan yang membawa kepada kesejahteraan dan kualiti kehidupan yang lebih baik kepada komuniti tempatan. Manakala, pembangunan alam sekitar bermaksud pembangunan yang dapat mengekalkan sumber sedia atau memperbaharui sumber untuk faedah bersama untuk generasi masa kini dan generasi masa depan seperti mengelakkan daripada berlaku pencemaran alam sekitar.

Oleh itu, setiap pembangunan pelancongan perlu mengambilkira aspek ekonomi, sosial budaya dan alam sekitar supaya wujudnya konsep pembangunan lestari. Rajah 1 menggambarkan impak ekonomi, sosial, budaya dan alam sekitar yang dibawa oleh pembangunan ke atas kesejahteraan dan kepuasan dalam kehidupan

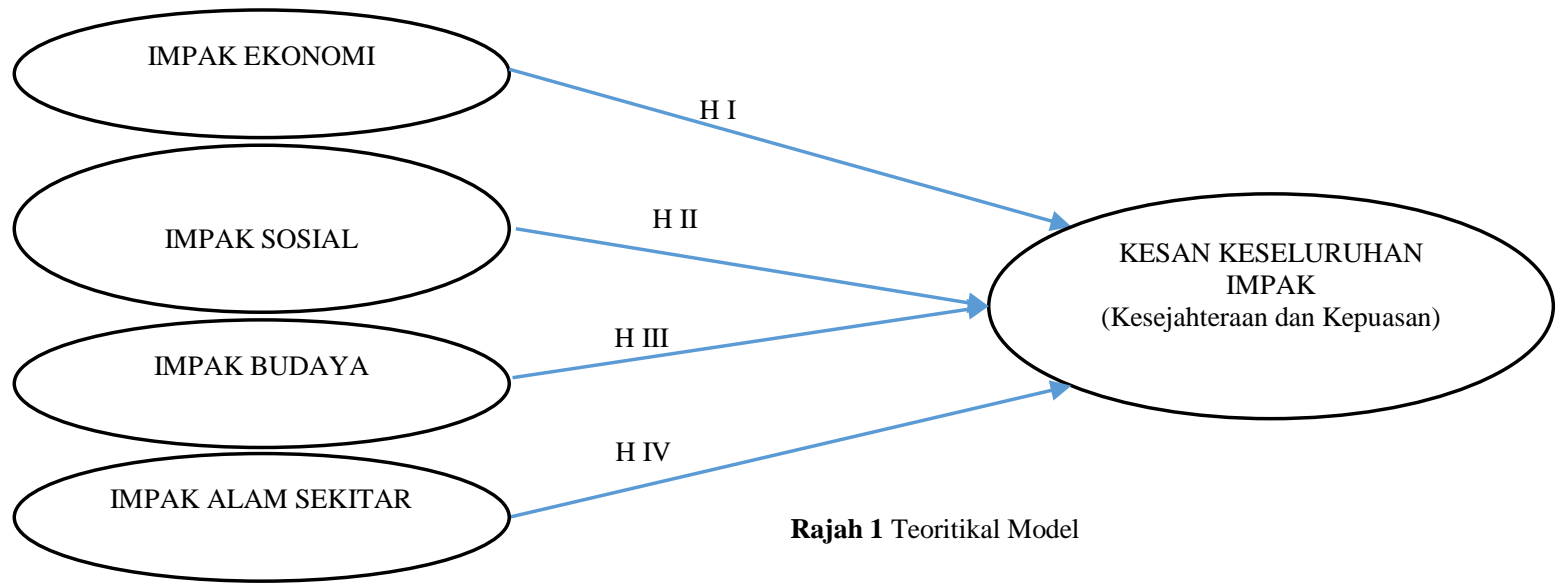

Terdapat beberapa kajian telah dilakukan oleh penyelidik lepas untuk melihat kesan keseluruhan impak pembangunan pelancongan terhadap kehidupan komuniti tempatan antaranya Snaith \& Haley (1999); Andereck \& Vogt (2000); Andriotis (2005); Wang \& Pfister (2008); Eshliki \& Kaboudi (2012); dan Kim et al., (2013). Hasil kajian terdahulu mendapati bahawa pembangunan pelancongan meningkatkan taraf kehidupan dan kesejahteraan komuniti tempatan (Andereck \& Vogt, 2000, Andriotis, 2005, Wang \& Pfister, 2008). Manakala, menurut kajian yang dilakukan oleh Kim et al., (2013) wujudnya hubungan positif antara pembangunan pelancongan dan kepuasan dalam kehidupan komuniti tempatan. Pembangunan pelancongan juga memberi kesan positif kepada kualiti kehidupan komuniti tempatan (Eshliki \& Kaboudi, 2012). Kesan keseluruhan impak ini diukur berdasarkan dimensi atau item faktor ekonomi, sosial, budaya dan alam sekitar.

Oleh itu, pembangunan pelancongan perlu mengambilkira sumbangan kepada aktiviti ekonomi komuniti penduduk tempatan (Harrill, 2004, Andriotis, 2005). Sumbangan ini dilihat dari sudut peluang pekerjaan dan pengagihan faedah ekonomi bagi membolehkan masyarakat tempatan menjalankan kehidupan yang lebih baik (Fun et al., 2014). Peluang dan faedah tersebut menunjukkan kesan positif dalam pembangunan pelancongan (Chen, 2001, Nunkoo \& Ramkissoon, 2011). Penglibatan komuniti tempatan dalam aktiviti pelancongan juga dapat membasmi kemiskinan dengan memberi peluang kepada komuniti tempatan untuk menjalankan aktiviti perniagaan berasaskan pelancongan (Harrill, 2004). Oleh itu, faktor ekonomi merupakan faktor paling penting dilihat oleh komuniti tempatan.

Seterusnya, kajian yang dilakukan oleh Nunkoo \& Ramkissoon (2011) menunjukkan bahawa kesejahteraan dan kepuasan kehidupan komuniti tempatan dilihat dari sudut faktor sosial seperti keadaan keselamatan, kemahiran dan khidmat masyarakat. Faktor ini merupakan faktor penting dilihat oleh komuniti tempatan sama ada pembangunan membawa impak positif atau negatif. Menurut kajian yang dilakukan oleh Lankford (1994) pembangunan pelancongan membawa kepada perubahan positif dalam struktur masyarakat yang mana komuniti tempatan dapat meningkatkan kemahiran berkomunikasi. Sebaliknya, kajian yang dilakukan oleh Andriotis (2005) dan Dyer et al., (2007) menyatakan bahawa responden melahirkan rasa bimbang terhadap faktor sosial masyarakat. Mereka merasakan terdapat kesan negatif dari pembangunan pelancongan seperti peningkatan kadar jenayah. Maka, adalah penting untuk memahami impak pembangunan pelancongan terhadap sosial komuniti tempatan. 
Setiap kawasan geografi yang didiami oleh sesebuah komuniti mempunyai budaya dan amalan tersendiri. Mereka mewarisi dari turun temurun dan mengekalkannya hingga sekarang. Hasil daripada pembangunan pelancongan mempunyai impak jangka panjang dan menyebabkan perubahan dalam norma masyarakat dari segi nilai-nilai, kepercayaan, dan amalan budaya (Brunt \& Courtney, 1999). Misalnya, pembangunan pelancongan membawa budaya negatif dalam kehidupan komuniti tempatan seperti identiti budaya masyarakat terhakis (Yoon et al., 2001). Namun begitu, terdapat juga kesan positif kepada budaya komuniti tempatan seperti Brida et al., (2011) menunjukkan bahawa komuniti tempatan berpeluang mengkomersialkan budaya dan sukan tradisional tempatan kajian. Natijahnya, kebudayaan komuniti tempatan dapat dikekalkan dan dipelihara.

Pelancongan berkaitan rapat dengan penggunaan sumber alam semulajadi. Penggunaan sumber ini digunakan untuk melakukan aktiviti rekreasi seperti snorkeling, mendaki dan lain-lain. Terdapat kajian yang menyatakan kegiatan aktiviti ini membawa kemusnahan kepada alam semula jadi (Yoon et al., 2001). Walau bagaimanapun, kajian yang dilakukan oleh Byrd et al., (2008) di California Utara menunjukkan bahawa pembangunan pelancongan memberi impak positif kepada penjagaan dan pemuliharaan alam sekitar seperti meningkatkan tahap kebersihan kawasan pelancongan. Malah, pembangunan juga membawa kesan limpahan penjagaan kebersihan di kawasan tempat tinggal komuniti tempatan (Shukor et al., 2014). Selain itu, pelancongan berasaskan alam sekitar juga melibatkan penggunaan sumber ekonomi komuniti tempatan seperti laut. Sekiranya, pembangunan pelancongan yang dilakukan ke atas alam semulajadi mengganggu aktiviti ekosistem komuniti tempatan, maka ia akan mewujudkan tentangan dari kalangan mereka. Kajian yang dilakukan oleh Mason \& Cheyne (2000) menunjukkan bahawa komuniti tempatan merasa ketidakpuasan dengan projek-projek pembangunan pelancongan kerana pembangunan tersebut telah mengabaikan penjagaan dan pemuliharaan alam sekitar.

Berdasarkan tinjauan dan pengamatan daripada penyelidik lepas, dapat disimpulkan bahawa pembangunan pelancongan memberi impak sama ada positif mahupun negatif dan seterusnya memberi kesan keselurahan impak iaitu kesejahteraan dan kepuasan dalam kehidupan komuniti tempatan. Dengan mengambilkira teori kelestarian dan hujah kajian lepas, kajian ini ingin menganalisis tahap kebersetujuan pembangunan pelancongan dan menganalisis impak pembangunan pelancongan terhadap kehidupan komuniti tempatan di destinasi pelancongan Pulau Tioman. Hipotesis kajian adalah seperti berikut:-

Hipotesis (I) : Pembangunan pelancongan memberi kesan positif antara ekonomi dan kesan keseluruhan impak kepada komuniti tempatan Pulau Tioman.

Hipotesis (II) : Pembangunan pelancongan memberi kesan positif antara sosial dan kesan keseluruhan impak kepada komuniti tempatan Pulau Tioman.

Hipotesis (II) : Pembangunan pelancongan memberi kesan positif antara budaya dan kesan keseluruhan impak kepada komuniti tempatan Pulau Tioman.

Hipotesis (IV) : Pembangunan pelancongan memberi kesan positif antara alam sekitar dan kesan keseluruhan impak kepada komuniti tempatan Pulau Tioman.

\subsection{METODOLOGI}

\section{Lokasi Kajian}

Pulau Tioman menjadi destinasi pilihan kajian memandangkan pulau ini merupakan antara salah sebuah Taman Laut Malaysia yang giat dibangunkan sebagai destinasi pelancongan berasaskan pulau dan taman laut. Pembangunan ini berkait rapat antara komuniti tempatan dan impak pembangunan yang diperoleh oleh mereka. Pulau ini terletak di pantai timur Semenanjung Malaysia dengan keluasan 13,360 hektar,134 km persegi, $39 \mathrm{~km}$ panjang dan $12 \mathrm{~km}$ lebar iaitu antara negeri Pahang dan negeri Johor. Ia terbentuk daripada sejumlah sembilan (9) buah pulau iaitu Pulau Tulai, Pulau Labas, Pulau Chebeh, Pulau Sepoi, Pulau Gut, Pulau Seri Buat, Pulau Sembilang, Pulau Tokong Bara dan Pulau Tioman.

Selain itu, Pulau Tioman menjadi pilihan kerana kedatangan pelancongan kian meningkat saban tahun. Jumlah kedatangan pelancong telah direkodkan seramai 214,482 orang pada tahun 2012. Pada tahun 2013, kedatangan pelancong seramai 232,102 orang. Manakala pada tahun 2014 pula, seramai 268,784 orang pelancong terdiri daripada pelancong antarbangsa dan domestik. Peningkatan kedatangan pelancong dari pelbagai latar belakang bangsa dan budaya sudah tentu memberi kesan kepada sosial budaya komuniti tempatan. Komuniti tempatan dianggarkan lebih kurang lebih kurang 3,000 penduduk. Mereka bekerja sebagai nelayan, pekerja resort dan lain-lain.

Pengangkutan ke Pulau Tioman menggunakan pengangkutan air. Ia merupakan pengangkutan utama dari jeti Mersing. Jeti ini merupakan jeti yang paling popular dalam kalangan pelancong ke Pulau Tioman. Waktu yang paling sesuai untuk ke Pulau Tioman adalah dari Mac hingga Oktober. Pada waktu ini cuaca baik dan laut tidak bergelora.

Aktiviti utama pelancongan di Pulau Tioman seperti menyelam "scuba" dan "snorkeling" bagi menikmati 183 spesies terumbu karang dan pelbagai jenis ikan. Selain itu, terdapat juga aktivit bersiar-siar menaiki bot melihat perskitaran Pulau Tioman dan aktiviti 'rock climbing' di Kampung Juara dan Kampung Mukut. Manakala, terdapat kira-kira 78 buah resort dan calet di Salang, Air Batang, Tekek, Paya, Genting, Mukut dan Juara dibina dengan jumlah keseluruhan bilik 2,089 dengan 50\% dikategorikan sebagai mewah, 30\% sederhana dan $20 \%$ sebagai bilik bajet.

\section{Sampel dan Instrumen Kajian}

Pemilihan sampel dilakukan secara persampelan rawak bebas. Seramai 228 responden daripada 3,000 komuniti tempatan telah terlibat dalam kajian ini. Jumlah ini ditetapkan berdasarkan justifikasi bahawa jumlah tersebut dirasakan memadai untuk mewakili populasi komuniti penduduk Pulau Tioman. Dengan cara ini taburan responden adalah lebih menyeluruh dan berupaya untuk membuat penilaian dan dapat menganalisis kesan pembangunan pelancongan.

Instrumen kajian menggunakan borang soal selidik. Borang ini mengadungi tiga (3) bahagian utama dan diedarkan kepada komuniti penduduk Pulau Tioman. Bahagian pertama adalah berkaitan maklumat demografi penduduk Pulau Tioman. Soalan-soalan tersebut 
merangkumi aspek berkenaan jantina, bangsa, status perkahwinan, pekerjaan tetap, latar belakang pendidikan, dan pendapatan kasar bulanan (RM)

Bahagian kedua berkenaan soalan-soalan berkaitan kesan pembangunan pelancongan kepada komuniti tempatan. Faktor ini dipecahkan kepada empat (4) iaitu ekonomi, sosial, budaya dan alam sekitar. Bahagian ketiga berkenaan kesan keseluruhan impak pembangunan iaitu merujuk kepada tahap kesejahteraan dan kepuasan komuniti tempatan. Semua faktor tersebut diambil kira berdasarkan hujah penyelidik lepas yang telah mengemukakan item atau dimensi bagi faktor ekonomi, budaya, sosial dan alam sekitar (Snaith \& Haley 1999, Andereck \& Vogt, 2000, Mason \& Cheyne, 2000, Chen, 2001, Yoon et al., 2001, Andriotis, 2005, Wang \& Pfister, 2008, Byrd et al., 2008Nunkoo \& Ramkissoon, 2011, Brida et al., 2011, Eshliki \& Kaboudi 2012, Kim et al., 2013, Shukor at al. 2014, Fun et al., 2014). Maka, pengkaji telah membuat pengubahsuaian item atau dimensi bagi faktor agar bersesuaian dengan lokasi dan objektif kajian. Kesemua bahagian dua (2) menggunakan skala likert lima (5) mata meliputi mata 1 untuk "sangat tidak bersetuju" hingga mata 5 untuk "sangat bersetuju". Manakala Kesemua bahagian tiga (3) menggunakan skala likert lima (5) mata meliputi mata 1 untuk "sangat tidak puas" hingga mata 5 untuk "sangat puas".

\section{Kaedah Analisis}

Kajian ini menggunakan Structural Equation Modeling (SEM) untuk menilai kesesuaian model yang digunakan dalam kajian ini. SEM digunakan untuk menganalisis hubungan antara pemboleh ubah. Kaedah SEM sesuai menggunakan perisian Smart Partial Least Square 3 (SmartPLS 3) untuk menganalisis data. Analisis SmartPLS mengukur persamaan struktur linear mewakili hubungan sebab dan akibat antara pemboleh ubah.

SEM merangkumi tiga (3) analisis utama iaitu statistik deskriptif (min), Confirmatory Factor Analysis (CFA) dan ujian hipotesis model. Anlisa min digunakan untuk menjelaskan nilai purata tahap persetujuan responden terhadap item-item pemboleh ubah yang dibentangkan dalam soal selidik. Menggunakan skala lima (5) mata Likert, skala min di bawah 2.5 dikategorikan sebagai tidak penting/puas, manakala skala min 2.5 ke atas dianggap sebagai penting/puas (Salleh et al., 2011).

Manakala, analisis CFA adalah ujian outer loading dan Cronbach Alpha (CA). Nilai outer loading bagi setiap item pemboleh ubah bebas boleh haruslah sama atau melebihi 0.4 (Hair et al., 1998, Hulland, 1999). Jika nilai outer loading kurang 0.40, maka item pemboleh ubah tersebut akan dihapus atau dipadamkan dari dimensi faktor (Fornell \& Lacher, 1981). Nilai CA pula menunjukkan bahawa korelasi antara item pemboleh ubah. Nilai yang dicadangkan oleh oleh Hair et al. (2007) adalah nilai 0.6 dianggap sebagai mencukupi; nilai antara 0.6 hingga $<0.7$ sebagai sederhana; nilai antara 0.7 dan $<0.8$ sebagai baik; nilai antara 0.8 dan $<0.90$ sebagai sangat baik dan $\geq 0.9$ sebagai cemerlang.

Seterusnya, CFA juga digunakan untuk menilai validity, reliability of instrument dan discriminant validity. Validity untuk mengukur ketekalan, menilai sejauh mana item bebas daripada ralat rawak. Petunjuk dan composite reliability adalah dua langkah untuk menilai kebolehpercayaan konstruk (Fornell \& Larcker, 1981). Discriminant validity biasanya diperiksa dengan membandingkan punca kuasa dua AVE dengan korelasi antara konstruk tumpuan dan semua konstruk lain. Pemusatan setiap penunjuk adalah lebih tinggi bagi konstruk masing-masing daripada mana-mana konstruk lain (Chin, 1998).

Akhirnya, ujian regresi digunakan untuk menguji model hipotesis (Haenlein \& Kaplan, 2004). Ujian $t$-test digunakan dalam analisis model antara item dan faktor serta antara pemboleh ubah bebas dan pemboleh ubah bersandar. Ujian ini digunakan untuk menilai hubungan sama ada positif atau negatif dan berpandukan nilai signifikan sama ada hubungan tersebut penting atau tidak penting. Pekali $\mathrm{R}^{2}$ digunakan untuk menguji model formatif dalam SEM. $\mathrm{R}^{2}$ menerangkan sejauh mana kesan pemboleh ubah bebas terhadap pemboleh ubah bersandar. $\mathrm{R}^{2}$ menunjukkan peratusan pemboleh ubah bersandar yang boleh dijelaskan oleh pemboleh ubah bebas. Nilai $\mathrm{R}^{2}$ digunakan sebagai penunjuk kekuatan ramalan keseluruhan model. Nilai $\mathrm{R}^{2}$ adalah dianggap seperti berikut; 0.19-0.32 (lemah), 0.33-0.66 (sederhana) dan 0.67-1.00 (kuat) (Henseler et al., 2009).

Salah satu faktor yang paling penting dalam menilai model formatif adalah kesan Cohen's $f^{2}$ yang merujuk kepada sama ada pemboleh ubah bebas pendam mempunyai kesan yang besar ke atas pemboleh ubah bersandar. Jika $f^{2}$ adalah antara 0.02 dan 0.15 (atau $\left.0.0196<\mathrm{R}^{2}<0.130\right)$, kesan pemboleh ubah bebas terhadap pemboleh ubah bersandar adalah lemah; jika $f^{2}$ adalah antara 0.15 dan 0.35 (atau $0.130<\mathrm{R}^{2}<0.260$ ), kesannya adalah sederhana, dan jika $f^{2}$ adalah lebih daripada 0.35 (atau $0.260<\mathrm{R}^{2}$ ), pemboleh ubah bebas mempunyai kesan yang kuat ke atas pemboleh ubah bersandar (Cohen, 1988). Multicollinearity penunjuk formatif multicollinearity tinggi menunjukkan bahawa faktor mempunyai sifat bertindang antara faktor. Bagi tujuan mengesan multicollinearity, penyelidik memeriksa variance inflation factor (VIF). Nilai VIF haruslah tidak melebihi 10 (Petter et al., 2007).

\subsection{HASIL KAJIAN}

\section{Demografi Responden}

Kajian ini telah mendapat kerjasama dan maklumbalas daripada 228 orang komuniti penduduk Pulau Tioman. Berdasarkan Jadual 1, Sebanyak 60.1 peratus responden adalah lelaki dan 39.9 peratus adalah perempuan. Daripada aspek bangsa, didapati sebanyak 92.5 peratus terdiri daripada bangsa Melayu dan 6.6 peratus adalah berbangsa Cina serta baki 0.9 adalah India. Dari segi status perkahwinan, 135 orang sudah berkahwin dan 93 orang adalah bujang.

Majoriti umur responden terdiri daipada 30-50 tahun. Dalam aspek pendidikan para responden yang mempunyai taraf pendidikan sekolah menengah merupakan peratusan yang paling tinggi iaitu 59.6 peratus. Dari segi pekerjaan pula, kebanyakan terdiri daripada bekerja sendiri iaitu 154 orang (65.5 peratus). Sebanyak 67.5 peratus mempunyai sumber pendapatan bulanan antara bawah RM 1499.00 . Diikuti oleh kumpulan pendapatan antara RM 1500.00 - RM 2999.00 iaitu 30.7 peratus. 
Jadual 1 Demograpi responden pulau tioman

\begin{tabular}{|c|c|c|}
\hline Maklumat & Jumlah & Peratus (\%) \\
\hline Jantina: & 137 & 60.1 \\
\hline Lelaki & 91 & 39.9 \\
\hline Perempuan & & \\
\hline \multicolumn{3}{|l|}{ Bangsa: } \\
\hline Melayu & 211 & 92.5 \\
\hline Cina & 15 & 6.6 \\
\hline India & 2 & 0.9 \\
\hline \multicolumn{3}{|l|}{ Status perkahwinan: } \\
\hline Belum Berkahwin & 135 & 59.2 \\
\hline Berkahwin & 93 & 40.8 \\
\hline \multicolumn{3}{|l|}{ Umur: } \\
\hline Bawah 25 tahun & 43 & 18.9 \\
\hline $26-30$ tahun & 65 & 28.5 \\
\hline $31-35$ tahun & 45 & 19.7 \\
\hline $36-40$ tahun & 18 & 7.9 \\
\hline $41-45$ tahun & 31 & 13.6 \\
\hline 46 tahun ke atas & 26 & 11.4 \\
\hline \multicolumn{3}{|l|}{ Tahap pendidikan } \\
\hline Tiada pendidikan formal & 8 & 3.5 \\
\hline Sekolah rendah & 38 & 16.7 \\
\hline Sekolah menengah & 136 & 59.6 \\
\hline Diploma & 36 & 15.8 \\
\hline Ijazah & 10 & 4.4 \\
\hline \multicolumn{3}{|l|}{ Pekerjaan tetap } \\
\hline Bekerja sendiri & 154 & 67.5 \\
\hline Sektor Swasta & 50 & 21.9 \\
\hline Sektor Awam & 24 & 10.5 \\
\hline \multicolumn{3}{|l|}{ Purata pendapatan bulanan (RM): } \\
\hline Bawah 1499 & 119 & 52.2 \\
\hline 1500-2999 & 70 & 30.7 \\
\hline $3000-4499$ & 20 & 8.8 \\
\hline $4500-5999$ & 11 & 4.8 \\
\hline $6000-7499$ & 5 & 2.2 \\
\hline $7500-9000$ & 3 & 1.3 \\
\hline
\end{tabular}

\section{Analisis Min dan Outer Loading}

Jadual 2 menunjukkan ujian min dan outer loading bagi item faktor ekonomi, sosial, budaya dan alam sekitar. Item faktor ekonomi terdiri daripada sembilan (9) item pemboleh ubah bebas. Responden memberi maklum balas bahawa tahap kebersetujuan semua pemboleh ubah berada pada tahap bersetuju dengan nilai min 2.5 ke atas. Responden menyatakan item pemboleh ubah yang paling tinggi ialah "meningkatkan taraf hidup penduduk tempatan di kampung" (4.302). Bagi nilai min paling rendah bagi item pemboleh ubah ekonomi ialah "hasil pendapatan yang dijana boleh menyumbang kepada pembangunan kampung" (3.973). Semua outer loadings menunjukkan nilai antara 0.630 hingga 0.804 . Ini menunjukkan bahawa nilai 0.4 keatas adalah memenuhi syarat dan diterima.

Bagi faktor sosial, item pemboleh ubah bebas terdiri daripada tiga (3) item. Ujian min mendapati bahawa item "meningkatkan kemahiran berkomunikasi" merupakan min paling tinggi dengan nilai 4.210. Kedua, responden menyatakan mereka bersetuju dengan pembangunan pelancongan dapat "meningkatkan keselamatan kawasan" dengan nilai min 3.73. Item ketiga, mereka bersetuju pembangunan pelancongan dapat "mengurangkan jenayah dan gejala sosial kawasan kampong" (3.574). Ujian loading terhadap item pemboleh ubah sosial menunjukkan nilai outer loading melebihi 0.40 (Jadual 2).

Manakala bagi faktor budaya pula terdiri daripada sebelas (11) item pemboleh ubah bebas. Kesemua item dinyatakan oleh responden menunjukkan tahap bersetuju iaitu nilai 2.5 dan ke atas. Item pemboleh ubah menunjukkan min paling tinggi ialah "memelihara identiti budaya masyarakat" (4.131). Kedua tertinggi ialah "mengekalkan sukan tradisional atau sukan rakyat masyarakat tempatan" dengan nilai min 4.065. Bagi nilai min paling rendah pula, responden menyatakan item "identiti atau adat resam sebuah keluarga diperturunkan melalui proses sosialisasi" (3.644) hasil pembangunan pelancongan. Kedua terendah, item "membangunkan kumpulan kebudayaan" (3.748). Hasil ujian outer loading terhadap item budaya menunjukkan nilai loading antara melebihi 0.485 hingga 0.844 . Ini menunjukkkan semua nilai loading melepasi tahap sempadan (Jadual 2). Seterusnya, item sekitar terdiri daripada enam (6) pemboleh ubah bebas. Hasil ujian min mendapati bahawa item yang paling tinggi ialah "meningkatkan imej dan pemandangan kampung" (4.241) hasil daripada pembangunan pelancongan. Kedua, pembangunan pelancongan "meningkatkan tahap kebersihan kawasan kampung” (4.206) (Jadual 2)

Hasil analisis min dan outer loading bagi ekonomi, sosial, budaya dan alam sekitar didapati bahawa semua item faktor berapa pada tahap bersetuju ( $\geq 2.5$ ) dan nilai outer loading sama dan lebih 0.400 diterima dan memenuhi syarat. 
Jadual 2 Keputusan ujian min dan outer loading

\begin{tabular}{|c|c|c|c|}
\hline Item Faktor & Min & Sisihan Piawai & $\begin{array}{c}\text { Outer } \\
\text { Loading }\end{array}$ \\
\hline $\begin{array}{l}\text { Impak Ekonomi: } \\
\text { 1. } \\
\text { 2. Doleh memberikan peluang kerja. } \\
\text { 3. Meningkatkan taraf hidup penduduk tempatan di kampung. } \\
\text { 4. Hasil pendapatan yang dijana boleh menyumbang kepada pembangunan kampung. } \\
\text { 5. Menggalakkan kepelbagaian aktiviti ekonomi (kedai runcit dan cenderamata). } \\
\text { 6. Meningkatkan kuasa beli dan menyebabkan kualiti hidup yang lebih baik. } \\
\text { 7. Membasmi kemiskinan dalam kalangan penduduk di kampung. } \\
\text { 8. Meningkatkan peluang kemahiran dan pengetahuan individu. } \\
\text { 9. Meningkatkan tahap kecekapan pengurusan. }\end{array}$ & $\begin{array}{l}4.289 \\
4.271 \\
4.302 \\
3.973 \\
4.280 \\
4.127 \\
4.171 \\
4.122 \\
4.162\end{array}$ & $\begin{array}{l}0.945 \\
0.852 \\
0.823 \\
0.938 \\
0.812 \\
0.853 \\
0.774 \\
0.866 \\
0.902\end{array}$ & $\begin{array}{l}0.737 \\
0.804 \\
0.762 \\
0.636 \\
0.691 \\
0.712 \\
0.702 \\
0.630 \\
0.741\end{array}$ \\
\hline $\begin{array}{l}\text { Impak Sosial: } \\
\text { 1. Meningkatkan kemahiran berkomunikasi. } \\
\text { 2. Meningkatkan keselamatan kawasan. } \\
\text { 3. Mengurangkan jenayah dan gejala sosial kawasan kampung. }\end{array}$ & $\begin{array}{l}4.210 \\
3.763 \\
3.574\end{array}$ & $\begin{array}{l}0.844 \\
1.017 \\
1.160\end{array}$ & $\begin{array}{l}0.656 \\
0.816 \\
0.794\end{array}$ \\
\hline $\begin{array}{l}\text { Impak Budaya: } \\
\text { 1. Gaya hidup masyarakat tempatan dikekalkan. } \\
\text { 2. Identiti/ adat resam sebuah keluarga diperturunkan melalui proses sosialisasi. } \\
\text { 3. } \text { Budaya tempatan dikomersialkan bagi memenuhi permintaan pelancong. } \\
\text { 4. Membangunkan kumpulan kebudayaan. } \\
\text { 5. Mewujudkan masyarakat cintakan budaya. } \\
\text { 6. Mengetahui budaya luar. } \\
\text { 7. Meningkatkan kesedaran budaya tempatan dalam kalangan penduduk. } \\
\text { 8. Mengekalkan rumah tradisional tempatan. } \\
\text { 9. Mengekalkan sukan tradisional/rakyat masyarakat tempatan. } \\
\text { 10. Pemuliharaan kawasan sejarah. } \\
\text { 11. Memelihara identiti budaya masyarakat. } \\
\end{array}$ & $\begin{array}{l}3.973 \\
3.644 \\
3.815 \\
3.748 \\
3.881 \\
3.956 \\
3.868 \\
3.881 \\
4.065 \\
4.008 \\
4.131\end{array}$ & $\begin{array}{l}1.065 \\
1.091 \\
1.058 \\
1.134 \\
1.069 \\
0.960 \\
1.053 \\
1.098 \\
1.006 \\
1.082 \\
0.934 \\
\end{array}$ & $\begin{array}{l}0.686 \\
0.704 \\
0.659 \\
0.775 \\
0.844 \\
0.485 \\
0.730 \\
0.775 \\
0.831 \\
0.696 \\
0.832 \\
\end{array}$ \\
\hline $\begin{array}{l}\text { Impak Alam Sekitar: } \\
\begin{array}{ll}\text { 1. } & \text { Menggalakkan pemuliharaan alam semula jadi. } \\
\text { 2. } & \text { Meningkatkan imej dan pemandangan kampung. } \\
\text { 3. } & \text { Meningkatkan tahap kebersihan kawasan kampung. } \\
\text { 4. } & \text { Menggalakkan aktiviti kitar semula. } \\
\text { 5. } & \text { Melindungi hidupan liar seperti spesis burung migrasi. } \\
\text { 6. } & \text { Membangunkan lebih banyak taman laut dan kawasan rekreasi. }\end{array}\end{array}$ & $\begin{array}{l}4.202 \\
4.241 \\
4.206 \\
3.886 \\
3.833 \\
3.907\end{array}$ & $\begin{array}{l}0.918 \\
0.849 \\
0.927 \\
1.104 \\
1.085 \\
1.076\end{array}$ & $\begin{array}{l}0.778 \\
0.829 \\
0.803 \\
0.655 \\
0.671 \\
0.610\end{array}$ \\
\hline 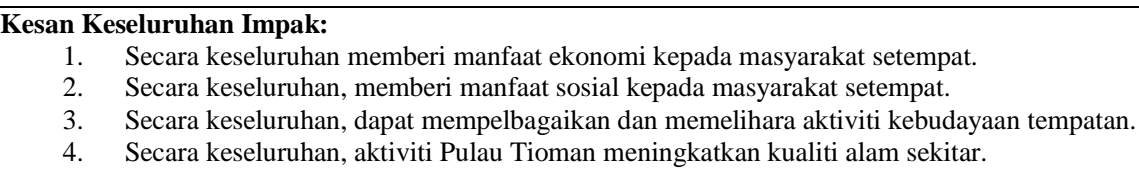 & $\begin{array}{l}4.303 \\
3.847 \\
4.162 \\
4.022\end{array}$ & $\begin{array}{l}0.839 \\
0.996 \\
0.912 \\
1.021\end{array}$ & $\begin{array}{l}0.520 \\
0.725 \\
0.805 \\
0.704\end{array}$ \\
\hline
\end{tabular}

Skala min impak faktor: 1 = Sangat Tidak Setuju, 2 = Tidak Puas, $3=$ Tidak Pasti, 4 = Setuju, 5 = Sangat Setuju

Skala kesan keseluruhan impak: 1 = Sangat Tidak Puas, $2=$ Tidak Puas, $3=$ Tidak Pasti, $4=$ Puas, $5=$ Sangat Puas

\section{Penilaian Kesahan Struktur Model}

Setelah melakukan analisis min dan outer loading. Analisis seterusnya berkenaan penilaian pengukuran model. Analisis penilaian pengukuran model adalah menilai kebolehpercayaan dan kesahihan dengan melakukan pengesahan faktor. Pengukuruan model mestilah memenuhi kriteria ujian Cronbach's Alpha (CA), Composite Reliability (CR), Average Variance Extracted (AVE) dan Discriminant Validity Analyses. Bagi analisis CA, CR and AVE, semua anggaran menunjukkan nilai berada di atas pada aras sempadan, iaitu 0.6 untuk CA dan CR (Bagozzi \& Yi, 1988, Hair, et, al. 2012) and 0.5 for AVE (Chin, 1998). Hasil ujian mendapat bahawa nilai antara 0.624 hing ga 0.913 dan hasil ujian CR menunjukkan nilai antara 0.801 hingga 0.927. Manakala ujian Average Variance Extracted (AVE) antara 0.547 hingga 0.873. Nilai AVE hendaklah sekurang-kurangnya 0.50 (Chin, 1998). Discriminant validity adalah diterima apabila punca kuasa dua AVE bagi setiap konstruk melebihi hubungan antara itu dan semua konstruk lain. Keputusan analisis kebolehpercayaan dan pengesahan yang digunakan dalam kajian ini menunjukkan berada dalam keadaan baik (Jadual 3 dan Jadual 4). 
Jadual 3 Keputusan ujian cronbach's alpha, composite reliability dan average variance extracted

\begin{tabular}{lccc}
\hline Faktor & $\begin{array}{c}\text { Cronbach's } \\
\text { Alpha }\end{array}$ & $\begin{array}{c}\text { Composite } \\
\text { Reliability }\end{array}$ & $\begin{array}{c}\text { Average } \\
\text { Variance } \\
\text { Extracted } \\
(\boldsymbol{A V E})\end{array}$ \\
\hline Impak Budaya & 0.913 & 0.927 & 0.541 \\
Impak Ekonomi & 0.880 & 0.903 & 0.511 \\
Impak Alam Sekitar & 0.821 & 0.870 & 0.531 \\
Kesan Keseluruhan Impak & 0.640 & 0.767 & 0.530 \\
Impak Sosial & 0.624 & 0.801 & 0.576 \\
\hline
\end{tabular}

Jadual 4 Keputusan ujian convergent dan discriminant validity analyses

\begin{tabular}{|c|c|c|c|c|c|}
\hline Faktors & Impak Budaya & $\begin{array}{c}\text { Impak } \\
\text { Ekonomi } \\
\end{array}$ & $\begin{array}{c}\text { Impak Alam } \\
\text { Sekitar }\end{array}$ & $\begin{array}{c}\text { Impak } \\
\text { Keseluruhan } \\
\end{array}$ & Impak Sosial \\
\hline Impak Budaya & 0.735 & & & & \\
\hline Impak Ekonomi & 0.473 & 0.715 & & & \\
\hline Impak Alam Sekitar & 0.630 & 0.512 & 0.729 & & \\
\hline Kesan Keseluruhan Impak & 0.722 & 0.543 & 0.671 & 0.728 & \\
\hline Impak Sosial & 0.469 & 0.381 & 0.465 & 0.489 & 0.759 \\
\hline
\end{tabular}

\section{Penilaian Struktur Model}

Analisis penilaian struktur model adalah untuk mengetahui kekuatan penerang setiap pemboleh ubah bebas terhadap pemboleh ubah bersandar. Berdasarkan Jadual 5, nilai variance inflation factor (VIF) adalah kurang daripada 10, ini menunjukkan bahawa tidak terdapat masalah multicollinearity antara pemboleh ubah bebas atau faktor. Nilai $\mathrm{R}^{2}$ menunjukkan 0.628 jumlah varians pemboleh ubah bersandar dijelaskan oleh pemboleh ubah bebas. Nilai ini menunjukkan data berada dalam keadaan sangat baik (Henseler et. al, 2009). Langkah terakhir dalam penilaian model struktur adalah untuk menilai kesan pemboleh ubah bebas tertentu pada pemboleh ubah bersandar. Ini boleh dicapai dengan memeriksa $f^{2}$. Nilai $f^{2}$ antara 0.019 hingga 0.264 masing-masing, yang dianggap kesan yang agak kecil (Cohan's, 1988).

\section{Penilaian Hipotesis}

Rajah 2 dan Jadual 5 menunjukkan analisis hubungan antara item faktor pemboleh bebas dan pemboleh ubah bebas serta hubungan antara faktor pemboleh ubah bebas dengan pemboleh ubah bersandar. Analisis ini bertujuan untuk melihat aliran regresi untuk menunjukkan kekuatan hubungan antara pemboleh ubah bebas dan pemboleh ubah bersandar. Kemudian, hasil ujian ini jelas akan menunjukkan hubungan yang signifikan di antara item dan faktor.

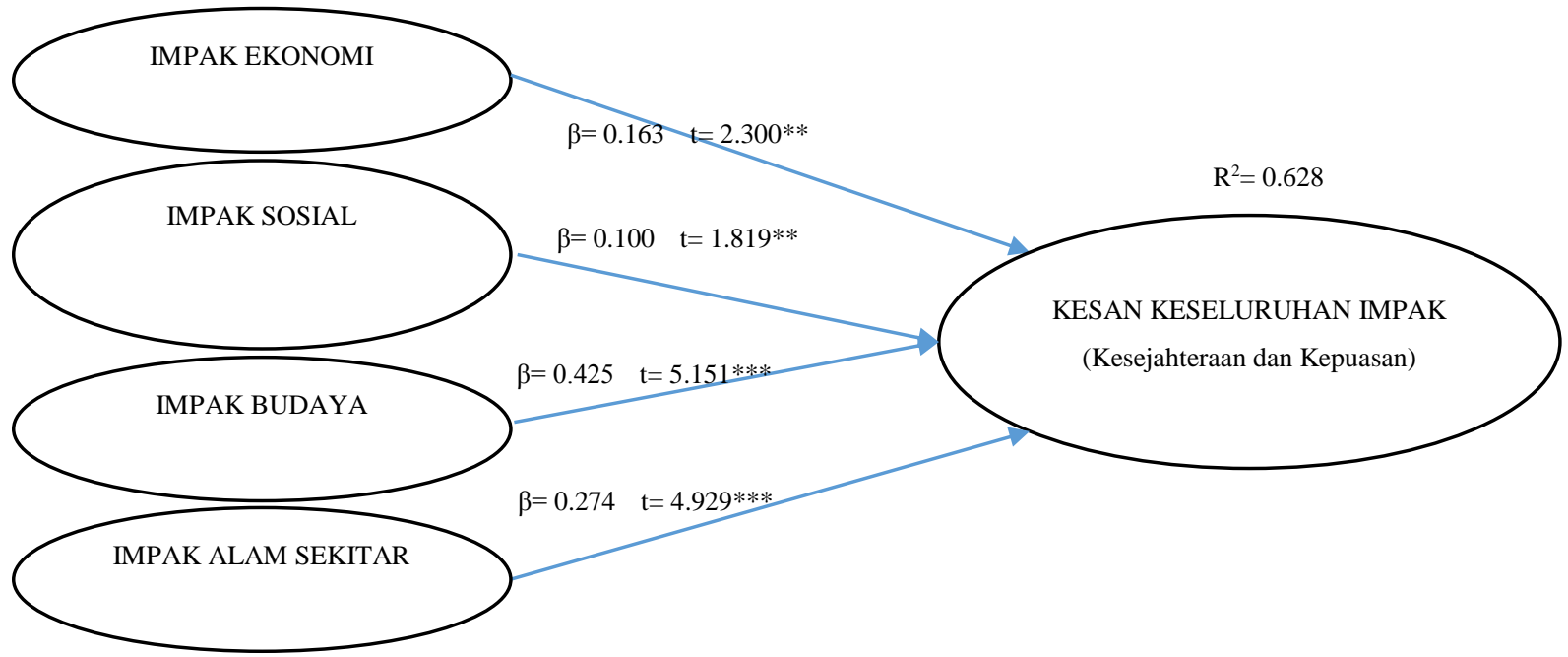

Rajah 2 Hasil Kajian

Signifikan: $* * *=0.010, * *=0.050, *=0.10, \beta=\beta$ eta, $\mathrm{t}=\mathrm{t}$-test 
Hasil ujian regresi bagi item faktor bagi ekonomi, sosial, budaya dan alam sekitar menunjukkan hubungan positif dan penting. Manakala analisis hubungan antara ekonomi, sosial, budaya dan alam sekitar terhadap kesan keseluruhan impak (kesejahteraan dan kepuasan) terhadap pembangunan pelancongan ditunjukkan dalam penilaian hipotesis berdasarkan Rajah 2. Analisis hipotesis I menunjukkan bahawa terdapat hubungan positif antara impak ekonomi dan kesan keseluruhan impak yang mewujudkan rasa kesejahteraan dan kepuasan kehidupan komuniti tempatan dengan nilai pekali 0.163 . Hasil ini menunjukkan bahawa pembangunan pelancongan memberi faedah dan sumbangan kepada ekonomi komuniti tempatan serta faktor ini mempunyai pengaruh yang penting terhadap pembangunan pelancongan (ttest=2.300 sig=0.010). Antara faedah yang diperoleh dari pembangunan pelancongan ialah dapat memberi peluang pekerjaan kepada komuniti tempatan. Selain itu, pembangunan pelancongan juga menggalakkan kepelbagaian aktiviti ekonomi seperti kedai runcit, cenderamata dan kafe siber.

Bagi hipotesis II pula, analisis mendapati bahawa terdapat hubungan positif antara impak sosial dan kesan keseluruhan impak dalam kehidupan komuniti tempatan $(\beta=0.100)$ dan ujian t-test menunjukkan nilai 1.819 serta nilai signifikan pada aras keertian 0.05. Ini menunjukkan bahawa pembangunan pelancongan memberi faedah dari sudut sosial komuniti tempatan. Hal ini kerana, pembangunan pelancongan dapat meningkatkan kemahiran berkomunikasi dan meningkatkan keselamatan kawasan. Ia juga dapat mengurangkan jenayah dan gejala sosial kawasan kampung komuniti tempatan.

Seterusnya, analisis antara impak budaya dan kesan keseluruhan impak yang menunjukkan bahawa komuniti tempatan berasa sejahtera dan puas dalam kehidupan pada hipotesis III. Hasil ujian mendapati bahawa terdapat kesan positif antara pembangunan pelancongan dan faktor budaya $(\beta=0.425)$ serta hubungan ini mempunyai pengaruh penting antara pemboleh ubah. Ini dibuktikan dengan nilai $t$-test 5.151 dan signifikan pada aras keertian 0.010 . Faedah yang diperoleh daripada pembangunan pelancong ialah identiti dan adat resam sebuah keluarga diperturunkan melalui proses sosialisasi. Hasil pembangunan pelancongan juga meningkatkan kesedaran budaya tempatan dalam kalangan penduduk.

Hipotesis IV ialah persepsi komuntiti tempatan terhadap pembangunan pelancongan bagi faktor penggunaan alam sekitar. Analisis path analysis menunjukkan bahawa terdapat hubungan positif antara kedua-dua pemboleh ubah $(\beta=0.274)$ dengan nilai $t$-test 4.929 . Hasil nilai $t$-test menunjukkan terdapat pengaruh antara impak alam sekitar dan kesan keseluruhan impak dalam kehidupan komuniti tempatan. Pembangunan pelancongan ini dapat menggalakkan pemuliharaan alam semula jadi. Ia juga dapat meningkatkan tahap kebersihan kawasan kampung.

Hasil analisis hipotesis menunjukkan bahawa keempat-empat faktor ekonomi, sosial, budaya dan alam sekitar mempunyai impak positif dan mempunyai pengaruh penting terhadap pembangunan pelancongan. Dapat disimpulkan bahawa, pembangunan pelancongan di destinasi Pulau Tioman memenuhi konsep pembangunan lestari. 
Jadual 5. Ujian hipotesis

\begin{tabular}{|c|c|c|c|c|c|c|c|c|c|c|}
\hline \multicolumn{4}{|c|}{ 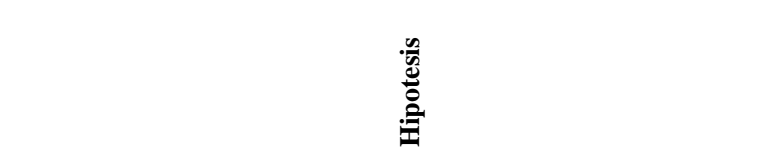 } & \multirow{2}{*}{ 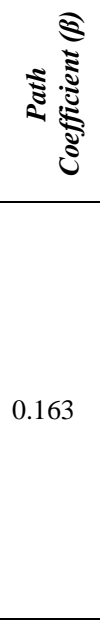 } & \multirow{2}{*}{$2.300^{* * * *}$} & \multirow{2}{*}{$\begin{array}{c}2 \\
0.049 \\
0.04\end{array}$} & \multirow{2}{*}{$\begin{array}{c}\Xi \\
1.455\end{array}$} & Item Faktor & 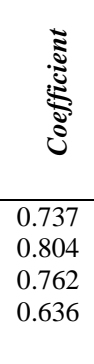 & \multirow{2}{*}{$\begin{array}{c}\text { ذँ } \\
\\
14.868 * * * \\
20.487 * * * \\
16.965 * * * \\
12.274^{* * *} \\
13.048^{* * * *} \\
17.174^{* * * *} \\
13.349^{* * *} \\
12.516^{* * *} \\
20.520^{* * *} \\
\end{array}$} \\
\hline I & $\begin{array}{l}\text { Impak } \\
\text { Ekonomi }\end{array}$ & $\rightarrow$ & $\begin{array}{c}\text { Kesan Keseluruhan Impak } \\
\text { (Kesejahteraan dan Kepuasan) }\end{array}$ & & & & & $\begin{array}{ll}\text { 1. } & \text { Boleh memberikan peluang kerja. } \\
\text { 2. } & \text { Dapat menambah pendapatan sampingan keluarga } \\
\text { 3. } & \text { Meningkatkan taraf hidup penduduk tempatan di kampung. } \\
\text { 4. } & \text { Hasil pendapatan yang dijana boleh menyumbang kepada } \\
\text { pembangunan kampung. } \\
\text { 5. }\end{array}$ & $\begin{array}{l}0.737 \\
0.804 \\
0.762 \\
0.636 \\
\\
0.691 \\
\\
0.712 \\
\\
\\
0.702 \\
\end{array}$ & \\
\hline II & Impak Sosial & $\rightarrow$ & $\begin{array}{l}\text { Kesan Keseluruhan Impak } \\
\text { (Kesejahteraan dan Kepuasan) }\end{array}$ & 0.100 & $1.819^{* *}$ & 0.019 & 1.392 & $\begin{array}{l}\text { 1. Meningkatkan kemahiran berkomunikasi. } \\
\text { 2. Meningkatkan keselamatan kawasan. } \\
\text { 3. Mengurangkan jenayah dan gejala sosial kawasan kampung }\end{array}$ & $\begin{array}{l}0.656 \\
0.816 \\
0.794 \\
\end{array}$ & $\begin{array}{l}8.098 * * * \\
17.559 * * * \\
15.953 * * *\end{array}$ \\
\hline III & Imapk Budaya & $\rightarrow$ & $\begin{array}{c}\text { Kesan Keseluruhan Impak } \\
\text { (Kesejahteraan dan Kepuasan) }\end{array}$ & 0.425 & $5.151^{* * *}$ & 0.264 & 1.840 & 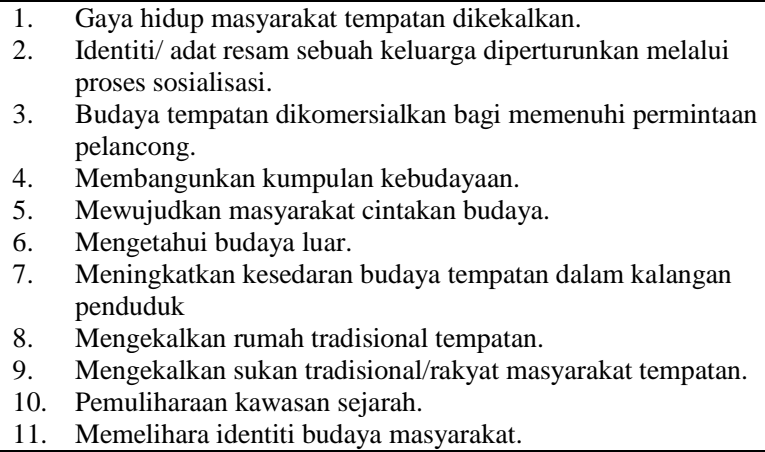 & $\begin{array}{l}0.686 \\
0.704 \\
\\
0.659 \\
\\
0.775 \\
0.844 \\
0.485 \\
0.730 \\
\\
0.775 \\
0.831 \\
0.696 \\
0.832\end{array}$ & $\begin{array}{l}13.996^{* * * *} \\
13.192^{* * *} \\
9.665^{* * * *} \\
\\
22.716^{* * *} \\
35.243^{* * *} \\
5.722^{* * *} \\
15.376^{* * *} \\
23.760^{* * *} \\
30.512^{* * *} \\
15.329^{* * *} \\
31.513^{* * *}\end{array}$ \\
\hline IV & $\begin{array}{l}\text { Impak Alam } \\
\text { Sekitar }\end{array}$ & $\rightarrow$ & $\begin{array}{c}\text { Kesan Keseluruhan Impak } \\
\text { (Kesejahteraan dan Kepuasan) }\end{array}$ & 0.274 & $4.929 * * *$ & 0.105 & 1.911 & $\begin{array}{ll}\text { 1. } & \text { Menggalakkan pemuliharaan alam semula jadi. } \\
\text { 2. } & \text { Meningkatkan imej dan pemandangan kampung. } \\
\text { 3. } & \text { Meningkatkan tahap kebersihan kawasan kampung. } \\
\text { 4. } & \text { Menggalakkan aktiviti kitar semula. } \\
\text { 5. } & \text { Melindungi hidupan liar seperti spesis burung migrasi. } \\
\text { 6. } & \text { Membangunkan lebih banyak taman dan kawasan rekreasi. }\end{array}$ & $\begin{array}{l}0.778 \\
0.829 \\
0.803 \\
0.655 \\
0.671 \\
0.610\end{array}$ & $\begin{array}{l}23.020^{* * *} \\
33.833^{* * *} \\
25.996^{* * *} \\
12.096^{* * *} \\
13.520^{* * *} \\
10.150^{* * *}\end{array}$ \\
\hline
\end{tabular}




\subsection{KESIMPULAN}

Pembangunan pelancongan adalah penting untuk memenuhi keperluan dan permintaan pelancong. Namun begitu, pembangunan pelancong membawa kesan sama ada positif mahupun negatif kepada komuniti tempatan. Ini kerana, pembangunan tidak terlepas daripada melibatkan komuniti tempatan di sesebuah kawasan pelancongan. Pembangunan pelancongan membawa impak kepada komuniti tempatan dari aspek pembangunan ekonomi, pembangunan sosial, pembangunan budaya dan pembangunan alam sekitar. Hasil pembangunan ini haruslah mencapai keseimbangan dan kepbertujeuanrluan keempat-empat aspek supaya dapat memenuhi konsep pembangunan lestari.

Kajian ini dijalankan di Pulau Tioman bertujuan untuk meninjau, mengenalpasti dan menilai impak pembangunan pelancongan kepada komuniti tempatan yang terdiri daripada 3,000 komuniti tempatan. Berdasarkan hasil dapatan kajian menunjukkan bahawa pembangunan pelancongan di Pulau Tioman membawa impak positif kepada komuniti tempatan dari segi faktor ekonomi, sosial, budaya dan alam sekitar dikalangan komuniti tempatan. Ini dibuktikan dengan penilaian kesemua dimensi atau item faktor berada tahap bersetuju terhadap impak pembangunan pelancongan. Hal ini menunjukkan bahawa pembangunan yang dijalankan oleh pihak berkepentingan mengambilkira kepentingan komuniti tempatan.

Hasil kajian ini juga mencerminkan kejayaan pembangunan pelancongan di destinasi pelancongan Pulau Tioman. Hal ini kerana, pembangunan pelancongan yang dijalankan memenuhi keperluan ekonomi komuniti tempatan dalam meningkatkan taraf hidup dengan memberi peluang pekerjaan. Secara tidak langsung ia dapat mengurangkan jurang sosioekonomi dan dapat membasmi kemiskinan. Selain itu, pembangunan pelancongan di Pulau Tioman membuka peluang kepada komuniti tempatan untuk menjalankan aktiviti ekonomi seperti kedai runcit dan cenderamata.

Pembangunan pelancongan di Pulau Tioman juga berjaya mengekalkan dan mengembangkan budaya serta adat resam sebuah keluarga dan diperturunkan melalui proses sosialisasi. Malah, budaya mereka dapat dikomersialkan bagi memenuhi permintaan pelancong disamping meningkatkan kesedaran budaya tempatan, mengekalkan sukan tradisional atau sukan masyarakat tempatan dalam kalangan komuniti tempatan. Seterusnya, pemuliharaan dan perlindungan alam sekitar berjaya diterapkan dalam proses pembangunan di Pulau Tioman. Hal ini dapat dapat dilihat melalui penilai yang dibuat oleh komuniti tempatan yang menunjukkan bahawa pembangunan pelancongan dapat meningkatkan kebersihan kawasan kediaman dan kawasan rekreasi serta melindungi hidupan liar. Hasil daripada kajian ini menunjukkan semua faktor membawa impak positif kepada komuniti tempatan, ia menimbulkan perasaan kesejahteraan dan kepuasan dalam kalangan mereka. Oleh itu, pembangunan pelancongan di Pulau Tioman haruslah diteruskan selagi mana pembangunan membawa kebaikan kepada komuniti tempatan.

Secara kesimpulanya, pembangunan pelancongan di destinasi pelancongan Pulau Tioman boleh dijadikan model sebagai panduan bagi pembangunan pelancongan kawasan baru. Hal ini kerana, pembangunan pelancongan di Pulau Tioman memenuhi konsep kelestarian yang mana ia mengambilkira kesan kepada komuniti tempatan dari faktor ekonomi, sosial, budaya dan alam sekitar. Oleh itu, pihak berkepentingan seperti kerajaan dan swasta haruslah meneliti dan mengambilkira keempat-empat dimensi atau item faktor dalam proses pembangunan supaya wujudnya pembangunan lestari.

\section{Rujukan}

Andereck, K. L., \& Vogt, C. A. (2000). The Relationship Between Residents' Attitudes Toward Tourism And Tourism Development Options. Journal of Travel Research, 39(1), 27-36.

Andriotis, K. (2005). Community Groups' Perceptions Of And Preferences For Tourism Development: Evidence from Crete. Journal of Hospitality \& Tourism Research, 29(1), 67-90.

Bagozzi, R. P., \& Yi, Y. (1988). On the Evaluation Of Structural Equation Models. Journal of the Academy of Marketing Science, 16, $74-94$.

Brida, J. G., Riaño, E., \& Aguirre, S. Z. (2011). Residents' Attitudes And Perceptions Towards Cruise Tourism Development: A Case Study of Cartagena de Indias (Colombia). Tourism and Hospitality Research, 11(3), 181-196.

Brunt, P., \& Courtney, P. (1999). Host Perceptions Of Sociocultural Impacts. Annals of Tourism Research, 26(3), 493-515.

Butler, R. W. (1991). Tourism, Environment, and Sustainable Development. Environmental Conservation, 18(3), 201-209.

Byrd, E. T., Cárdenas, D. A., \& Greenwood, J. B. (2008). Factors of Stakeholder Understanding Of Tourism: The Case of Eastern North Carolina. Tourism and Hospitality Research, 8(3), 192-204

Chen, J. S. (2001). Assessing and Visualizing Tourism Impacts From Urban Residents' Perspectives. Journal of Hospitality \& Tourism Research, 25(3), 235-250.

Chin, W. W. (1998). The Partial Least Squares Approach To Structural Equation Modeling. In G. A. Marcoluides (Ed.), Modern Methods For Business Research. 295-336. London: Lawrence Erlbaum Associates.

Cohen, J. (1988). Statistical Power Analysis For The Behavioral Sciences. Hillsdale, NJ: Lawrance Erlbaum.

Dyer, P., Gursoy, D., Sharma, B., \& Carter, J. (2007). Structural Modeling Of Resident Perceptions Of Tourism And Associated Development on the Sunshine Coast, Australia. Tourism Management, 28(2), 409-422.

Emas, R. (2015). The Concept of Sustainable Development: Definition and Defining Principles. Florida International University.

Eshliki, S. A., \& Kaboudi, M. (2012). Community Perception Of Tourism Impacts And Their Participation In Tourism Planning: A Case Study of Ramsar, Iran. Procedia-Social and Behavioral Sciences, 36, 333-341.

Fornell, C, \& Larcker, D. (1981). Evaluating Structural Equation Models With Unobserved Variable And Measurement Error. Journal of Marketing Research, 18, 3950.

Fun, F. S., Chiun, L. M., Songan, P., \& Nair, V. (2014). The Impact Of Local Communities' Involvement And Relationship Quality On Sustainable Rural Tourism In Rural Area, Sarawak. The Moderating Impact Of Self-Efficacy. Procedia-Social and Behavioral Sciences, 144, 60-65.

Haenlein, M. \& Kaplan, A. M. (2004). A Beginner's Guide to Partial Least Squares Analysis. Understanding Statistics, 3(4), $283-297$.

Hair, J. F., Anderson, R. E., Tatham, R. L., \& Black, W. C. (1998). Multivariate data analysis. NJ: Prentice Ha 11 International, Inc.

Hair, J., Money, A., Page, M., \& Samouel, P. (2007). Research Methods For Business, England: John Wiley \& Son Ltd.

Hair, J.F., Sarstedt, M., Ringle, C.M. \& Mena, J.A., (2012). An Assessment Of The Use Of Partial Least Squares Structural Equation Modeling In Marketing Research. Journal of the Academy of Marketing Science, 40(3), 414-433.

Harrill, R. (2004). Residents' Attitudes Toward Tourism Development: A Literature Review With Implications For Tourism Planning. Journal of Planning Literature, $18(3), 251-266$

Henseler, J., Ringle, C., \& Sinkovics, R. (2009). The Use Of Partial Least Squares Path Modeling In International Marketing. Advances in International Marketing, 20(2009), 277-320.

Hulland, J. (1999). Use of Partial Least Squares (PLS) In Strategic Management Research: A Review Of Four Recent Studies. Strategic Management Journal, 20(2), 195-204. 
Kim, K., Uysal, M., \& Sirgy, M. J. (2013). How Does Tourism In A Community Impact The Quality Of Life Of Community Residents? Tourism Management, 36, $527-540$.

Lankford, S. V. (1994). Attitudes and Perceptions towards Tourism and Rural Regional Development. Journal of Travel Research, 32(4), 35-43.

Mason, P., \& Cheyne, J. (2000). Residents' Attitudes to Proposed Tourism Development. Annals of Tourism Research, 27, $391-411$.

Nunkoo, R., \& Ramkissoon, H. (2011). Residents' Satisfaction With Community Attributes And Support For Tourism. Journal of Hospitality \& Tourism Research, 35(2), 171-190.

Petter, S., Straub, D., Rai, A. (2007). Specifying Formative Constructs In Information Systems Research. MIS Quarterly, 31 (4), $623-656$.

Salleh, N. H. M., Sarmidi, T., Othman, O., Jaafar, A.H. \& Raudha M. R. 2011. Kepuasan Dan Kesetiaan Pelancong Domestik terhadap Destinasi Pelancongan Pulau Kapas. Journal of Tropical Marine Ecosystem, 1(2011), 10-21.

Shukor, M. S., Salleh, N. H. M., Othman, R., \& Idris, S. H. M. (2014). Perception of Homestay Operators Towards Homestay Development In Malaysia. Jurnal Pengurusan, 42, 3-17.

Snaith, T., \& Haley, A. (1999). Residents' Opinions Of Tourism Development In The Historic City of York, England. Tourism Management, $20(5), 595-603$.

United Nations General Assembly. (1987). Report of The World Commission On Environment And Development: Our Common Future. Oslo, Norway: United Nations General Assembly, Development and International Co-operation: Environment.

Wang, Y. A., \& Pfister, R. E. (2008). Residents' Attitudes Toward Tourism And Perceived Personal Benefits In A Rural Community. Journal of Travel Research. 84 93.

Yoon, Y., Gursoy, D., \& Chen, J. S. (2001). Validating a Tourism Development Theory With Structural Equation Modeling. Tourism Management, 22(4), 363-372. 